\title{
$\mathrm{PC}$ 기반의 SISI 검사 소프트웨어 개발
}

강덕훈 $^{1}$, 송복득 ${ }^{1}$, 신범주 $^{1^{*}}$, 이광호 $^{2}$, 김진동 $^{3}$, 전계록 $^{3}$, 왕수건 $^{4}$

${ }^{1}$ 부산대학교 생명자원대학 바이오메디컬공학과, ${ }^{2}$ 경일대학교 공과대학 전자정보통신공학과,

${ }^{3}$ 부산대학교 의과대학 의공학교실, ${ }^{4}$ 부산대학교 의과대학 이비인후과교실

\section{Development of SISI Test Software based on PC}

\author{
Deok-Hun Kang ${ }^{1}$, Bok-Deuk Song ${ }^{1}$, Bum-Joo Shin ${ }^{1 *}$, Kwang-Ho Lee ${ }^{2}$, \\ Jin-Dong $\mathrm{Kim}^{3}$, Gye-Rok Jeon ${ }^{3}$ and Soo-Geun Wang ${ }^{4}$ \\ ${ }^{1}$ Department of Biomedical Engineering, College of Natural Resource and Life Science, Pusan \\ National University \\ ${ }^{2}$ Department of Electronic Information \& Telecommunication Engineering, School of Engineering, \\ Kyungil University, \\ ${ }^{3}$ Department of Biomedical Engineering, \\ ${ }^{4}$ Department of Otolaryngology\}, School of Medicine, Pusan National University
}

\begin{abstract}
요 약 미세증가감수지수 검사는 감각신경성난청의 세부 병변을 감별하기 위하여 사용되는 누가현상을 판별하는 검 사이다. 본 논문은 PC 기반 소프트웨어로 구현한 미세증가감수지수 검사 소프트웨어를 기술한다. 구현된 소프트웨어 는 검사자의 검사 참여 유·무에 따라 수동 검사와 자동 검사의 두 가지 모드를 제공함으로써 경제적인 검사가 진행 될 수 있게 한다. 또 필요할 경우에 자동으로 차폐를 수행한다. 그리고 $1 \mathrm{~dB}$ 의 순간 상승음에 대한 검사뿐만 아니라 $2 \mathrm{~dB}$ 와 $5 \mathrm{~dB}$ 상승음에 대한 검사도 지원함으로써 보다 정확한 검사 결과를 얻을 수 있도록 한다.
\end{abstract}

\begin{abstract}
SISI(Short Increment Sensitivity Index) test is to identify recruitment phenomenon that is used to diagnose detailed lesion of sensory-neural hearing loss. This paper describes SISI test software implemented to personal computer(PC). This software supports two test modes, consisting of auto-mode and manual-mode, which are classified according to whether or not audiologist to lead test, thereby enabling cost effective test. In addition, it has been designed to perform automatic masking in case of necessity. And by supporting not only $1 \mathrm{~dB}$ increment but also 2 and $5 \mathrm{~dB}$ increment, SISI test program of this paper makes it possible to acquire more accurate test result
\end{abstract}

Key Words : Short Increment Sensitivity Index, PC based Audiometer, Automatic Masking

\section{1. 서론}

사람이 소리를 인지하기 위해 사용하는 다양한 기관들 에 병변이 발생할 경우 병변이 발생한 기관에 따라 서로 다른 특성을 갖는 난청이 발생한다. 따라서 난청의 정확 한 원인을 찾기 위해 난청의 특성을 이용하는 적절한 검 사법을 사용하는 것이 바람직하다.
순음청력검사에 의해 감각신경성난청(sensorineural hearing loss)으로 판정된 경우, 이 원인을 보다 정밀하게 판정하기 위한 방법으로 누가현상(loudness recruitment) 을 이용한다.

누가현상이란 역치보다 큰 음에 대한 가청음역이 축소 되어 역동범위(dynamic range)가 좁아져 있기 때문에 역 치보다 큰 강도의 음에 대해 작은 변화에도 민감하게 반

이 논문은 2009년도 정부(교육과학기술부)의 재원으로 한국연구재단의 지원을 받아 수행된 연구임(No. 2009-0083825) "교신저자 : 신범주(bjshin@pusan.ac.kr)

접수일 10 년 02 월 02 일 수정일 10 년 02 월 17 일 게재확정일 10 년 04 월 09 일 
응하는 현상이다. 이 같은 현상은 내이(inner ear)의 유모 세포(hair cell), 특히 외유모세포의 손상이 원인인 미로성 난청(cochlear hearing loss)을 가진 경우에 발생하게 된다. 정상인의 경우 역치보다 큰 자극음의 강도가 증가함에 따라 주관적인 음의 크기(loudness)가 비례적으로 증가하 는 반면 미로성 난청을 가진 사람은 청력손실이 존재하 면서도 불쾌 역치는 정상 청력을 가진 사람과 비슷하다 [2]. 따라서 누가현상은 와우 또는 청신경에 병변이 있을 때 발생하는 감각신경성 난청 중에서 미로성 난청을 구 분하는 중요한 지표가 된다.

누가현상을 판단하기 위해 사용되는 대표적인 청각검 사 방법이 미세증가감수지수(short increment sensitivity index, SISI) 검사법이다. SISI 검사법은 기도역치 이상의 강도를 갖는 순음을 연속적으로 들려주다 일정한 시간이 경과한 후 짧은 시간동안 음의 크기를 약간 증가시키고 이를 인지하는 가를 검사하는 방법이다. SISI 검사는 측 정 주파수 별로 증폭된 음의 크기를 감지하는 능력을 백 분율로 표시하기 때문에 일측성 난청뿐만 아니라 양측성 난청인 경우에도 적용될 수 있는 장점이 있다[2,4].

본 논문은 $\mathrm{PC}$ 를 기반으로 구현된 순음청력검사 소프 트웨어를 확장하여 SISI 검사 기능을 구현한 내용을 기술 한다. 구현된 소프트웨어는 검사자의 검사 참여 유·무에 따라 수동 검사와 자동 검사의 두 가지 모드를 제공함으 로써 검사자와 피검자 모두에게 효율적인 검사가 진행될 수 있도록 한다. 또한 피검자의 좌·우측 귀의 역치 차이를 바탕으로 자동 차폐 기능을 지원하며, 기도역치보다 $20 \mathrm{~dB}$ 큰 수준의 음에서 $1 \mathrm{~dB}$ 의 순간 상승음에 대한 검사 뿐만 아니라 $2 \mathrm{~dB}$ 과 $5 \mathrm{~dB}$ 상승음에 대한 검사 기능도 제공 한다. $1 \mathrm{~dB}$ 상승음 검사 이전에 $5 \mathrm{~dB}$ 및 $2 \mathrm{~dB}$ 상승음 검사 를 진행하여 피검자가 $1 \mathrm{~dB}$ 상승음 검사 환경에 적응할 수 있도록 함으로써 보다 정확한 검사 결과를 얻을 수 있 게 한다.

\section{2. 관련 연구}

본 연구와 관련된 기존 연구들을 분석하였다. [1]은 SISI 검사의 유효성을 입증하였다. [2]는 PC를 기반으로 하는 순음 청력 검사기를 개발하였으나, SISI 검사를 지 원하지 않는다. [3]은 휴대 가능한 PDA에 기도청력 검사 기능과 어음청력검사 기능을 제공한다는 특징을 가지고 있으나, 골도 청력에 관해 기술된 바 없을 뿐 아니라 SISI 검사를 지원하지 않는다. 반면 본 논문의 SISI 검사 소프 트웨어는 상기 [2]의 시스템을 확장하여 구현함으로써 기 도 및 골도 검사 기능에 더해 SISI 검사 기능을 추가함으
로써 검사 결과의 정밀도를 높이고 있다.

\section{3. 설계 및 구현}

SISI 검사는 $1 \mathrm{KHz}$ 와 $4 \mathrm{KHz}$ 의 주파수의 순음을 사용하 며, 변화된 음압을 감지하는 비율이 높을수록 음압의 미 세한 변화에 대해 감각적 변화폭이 큰 것이기 때문에 양 성으로 판단한다.

따라서 SISI 검사 소프트웨어는 기본적으로 순음 및 차폐음 생성, 그리고 검사 시 차폐 적용 필요성 판단, 차 폐 시에 차폐량을 결정하는 알고리즘이 지원되어야 한다. 또한 검사 진행 및 검사 결과를 출력하는 인터페이스 등 이 필수적으로 요구된다. 이 같은 기능을 제공하는 SISI 검사 소프트웨어를 Windows XP 운영체제를 갖는 PC에 서 멀티미디어 라이브러리 및 Visual $\mathrm{C}++$ 를 사용하여 개 발하였다. 본 장에서는 소프트웨어를 설계 및 구현한 내 용을 기술한다.

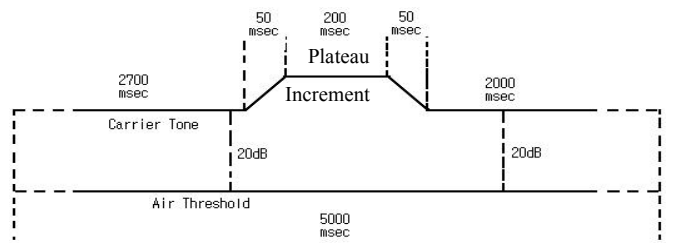

[그림 1] 기본 단위 SISI 검사음

\subsection{SISI 검사음 생성}

SISI 검사에서 사용하는 음의 특성은 그림 1 과 같다. 피검자의 기도역치보다 $20 \mathrm{~dB}$ 강한 순음을 연속적으로 들 려주다 일정한 시간동안 미세 증가된 음 $(1 \mathrm{~dB}$ 상승된 음 압)을 $200 \mathrm{~ms} \sim 250 \mathrm{~ms}$ 동안 들려준다. 피검자는 음압의 변 화를 인지할 경우, 사용자 인터페이스를 통해 인지 사실 을 체크한다. SISI 검사음은 일정 순간 음압이 상승한다 는 것을 제외하면, 기본적으로 순음청력검사 시스템의 기 도청력 검사에 사용되는 순음과 동일하다.

순음 생성을 위해 본 논문에서는 $44100 \mathrm{sample} / \mathrm{sec}$ 주 파수로 샘플링된 24 비트 PCM 포맷을 이용한다. 음압에 따라 진폭이 결정되는 디지털 값을 메모리에 저장하고 이를 기반으로 주파수에 따른 변화를 수용한다. 순음의 주파수에 따른 $\mathrm{n}$ 의 범위로 $0<\mathrm{n} \leq f_{s}$ 를 가지는 수식 1.1 을 이용하여 기본 정현파 데이터 테이블을 생성한다. 그리고 생성된 데이터 테이블을 정해진 주파수 간격 $(f)$ 으로 값 을 추출하여 정해진 음의 강도를 곱하여 검사음을 생성 한다. 이 방법은 검사를 위해 빈번하게 주파수와 음압 변 
경에 쉽게 대처할 수 있게 한다. 수식 1.2 는 음을 생성하 기 위해 사용된 함수를 나타내었다. 미세 증가 부분에서 는 음의 진폭이 변하게 된다.

$$
\begin{aligned}
y(n)= & \sin \left(2 \pi \frac{n}{f_{s}}\right) \\
y(n)= & A \cdot \sin \left(2 \pi f \frac{n}{f_{s}}\right) \\
& f: \text { frequency } \\
& f_{s}: \text { sampling rate } \\
& n: n^{\text {th }} \text { sample }
\end{aligned}
$$

본 논문에서는 SISI 검사음의 기본 단위 길이를 5 초로 하였고, 그림 1 과 같이 미세증가 음을 $300 \mathrm{~ms}$ 동안 생성 한다. 이 경우 실제 피검자에 전달되는 SISI 검사음이 안 정기(plateau)에 도달하기 전에 $50 \mathrm{~ms}$ 동안 선형적으로 상 승하게 되며, 다시 $50 \mathrm{~ms}$ 동안 선형적으로 하강하여 원래 음의 강도로 돌아오게 된다. 따라서 안정기의 길이는 $200 \mathrm{~ms}$ 가 된다. 실제 검사에서는 기본단위 SISI 검사음을 연속적으로 정해지는 횟수를 반복하여 검사를 진행한다.

\section{2 차폐음 생성}

기도 청력검사에서 검사측 귀에 검사음을 들려주면 두 개골의 진동에 의해 반대측 귀에 검사음이 감쇠된 수준 으로 전달되어 들리게 되는 현상이 발생한다. 이 현상을 방지하기 위해 검사귀의 반대측 귀에 특정 잡음을 들려 주는데 이를 차폐(masking)라고 한다. SISI 검사에서도 양측의 기도역치가 어느 수준 이상 차이가 날 경우 차폐 를 하는 것이 필요하다.

SISI 검사에서는 $1 \mathrm{KHz}$ 에서 검사측 귀의 기도 역치보 다 $20 \mathrm{~dB}$ 큰 음이 반대측 귀의 골도 역치보다 $40 \mathrm{~dB}$ 이상 작거나 $4 \mathrm{KHz}$ 에서 $50 \mathrm{~dB}$ 이상 작으면 차폐를 적용한다. 이 경우 사용될 음압은 검사측 귀의 기도역치 보다 $20 \mathrm{~dB}$ 큰 음압에 해당 주파수의 이간감쇠량 $(1 \mathrm{KHz} 40 \mathrm{~dB}, 4 \mathrm{KHz}$ $50 \mathrm{~dB})$ 을 뺀 값에서 반대측 귀의 해당 주파수 기도 · 골도 역치차(AirBoneGap)의 절대값을 더해준 값으로 결정한 다. $1 \mathrm{KHz}$ SISI 검사에서 식 2.1 을 만족할 경우 차폐를 하 며, 이때 차폐량의 결정 방법은 식 2.2 와 같다. $4 \mathrm{KHz}$ 의 경우 각 수식에서 $20 \mathrm{~dB}$ 값이 $30 \mathrm{~dB}$ 로 바뀐다.

$$
\begin{aligned}
& T E A T-20 d B \leq N T E B T \\
& T E A T-20 d B+|N T E A T-N T E B T|
\end{aligned}
$$

TE: Test Ear, NTE: Non Test Ear AT: Air Threshold, BT: Bone Threshold
ISO 389-4의 규정에는 차폐를 위해 협대역 잡음을 사 용할 것을 명시하고 있으며, 잡음의 기하학적 중심 주파 수가 검사음의 주파수와 일치해야 하며 주파수 대역이 $1 / 3$ 옥타브 내에 있어야 할 것을 명시하고 있다.[7] 본 논 문에서는 차폐를 위하여 협대역 가우시언 잡음을 사용한 다. 이를 위해서 Gaussian random number 생성기에 의해 생성된 광대역 잡음을 second order IIR bandpass filter를 이용하여 협대역 잡음으로 변환한다. Gaussian random number를 생성하는 다양한 방법들이 제안되었으나[13], 본 논문에서는 Polar 형식에 기반한 Box-Mullar 변환 방 식을 사용하였다. 실시간 특성이 좋은 IIR 필터를 구현하 기 위하여 G. D. Hillman이 제안한 방법[10]을 소프트웨 어로 구현하여 사용한다. 수식 3.1은 Hillman의 논문에서 제시한 bandpass filter의 전달 함수, 수식 3.1 3.4는 계수 를 계산하기 위한 수식을 나타내고 있다.

$$
\begin{aligned}
H(z) & =\frac{\alpha\left(1-z^{-2}\right)}{\frac{1}{2}-\gamma z^{-1}+\beta z^{-2}} \\
\beta & =\frac{1}{2}\left(\frac{1-\frac{1}{2} \delta \sin \theta_{0}}{1+\frac{1}{2} \delta \sin \theta_{0}}\right) \\
\gamma & =\left(\frac{1}{2}+\beta\right) \cos \theta_{0} \\
\alpha & =\left(\frac{1}{4}-\frac{1}{2} \beta\right) \\
\delta & : \text { Damping Factor } \\
\theta_{0} & : \text { Cutoff Frequency }
\end{aligned}
$$

\section{3 검사 알고리즘}

SISI 검사는 $1 \mathrm{KHz}$ 를 먼저 수행하고, $4 \mathrm{KHz}$ 를 수행한 다. 검사가 시작되면 피검자의 검사귀에 해당 주파수에 대한 기도역치 보다 $20 \mathrm{~dB}$ 큰 음을 생성한다. 이 때, 기도 역치와 골도역치 값의 차이를 바탕으로 차폐의 적용 여 부를 확인한다. 생성된 SISI 검사음을 정해진 횟수만큼 연속적으로 들려주고, 피검자가 상승음을 감지하는 경우 감지 횟수를 증가시킨다. 피검자가 상승음을 감지한 횟수 를 SISI 검사음의 총 반복 횟수로 나누어 피검자의 인지 율(\%)을 구한다. 그림 2는 SISI 검사의 진행 순서를 나타 내었다.

누가현상 판정은 인지율이 $70 \%$ 이상일 경우 완전누가 현상, $25 \sim 65 \%$ 일 경우 불완전누가현상, $20 \%$ 이하인 경 우 누가현상 음성으로 판정한다. 그리고 완전누가현상일 경우에는 감각신경성 난청, 누가현상 음성일 경우에는 전 음성 난청, 불완전 누가현상일 경우에는 혼합성 난청으로 
판정한다.[1]

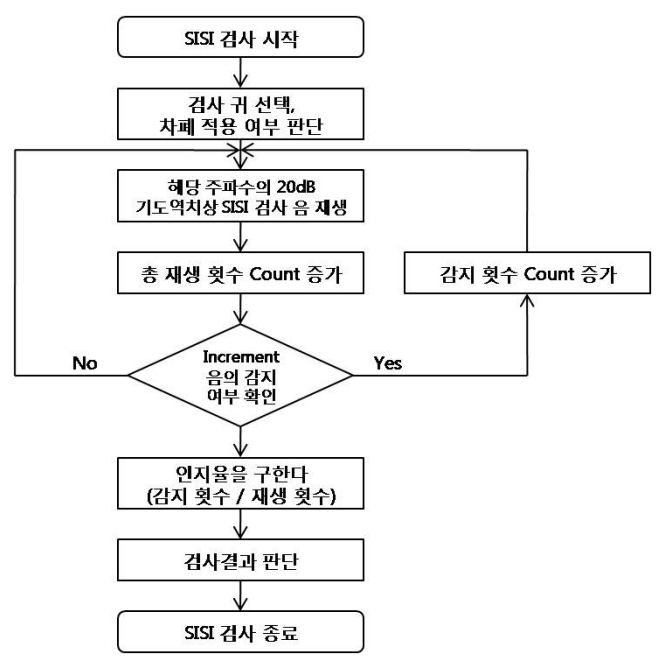

[그림 2] SISI 검사 진행도

\section{4 쓰레드 구성}

본 논문에서 구현한 소프트웨어는 3 개의 쓰레드로 구 성된다. 메인(Main) 쓰레드 외에 HearingTestThread와 AudiometerThread를 추가로 사용한다.

Main 쓰레드에서는 검사에 필요한 다이얼로그를 보여 주고 피검자 정보를 관리하며 검사 결과를 출력한다. HearingTestThread는 자동 모드와 수동 모드 검사를 시작 하기 위한 쓰레드이다. 만약 수동 모드가 선택되면 검사 귀, 주파수, 음압 $(\mathrm{dB})$, 차폐 적용 여부 등을 판단하여 설 정에 필요한 값들을 변수에 저장하고 이 값들을 바탕으 로 검사음을 메모리에 생성한다.

마지막으로 AudiometerThread는 실제 메모리에 생성 된 검사음을 재생, 정지, 일시정지 하는 쓰레드이다. 그리 고 이 쓰레드는 검사음이 헤드폰으로 출력될 때 상승음 이 발생되는 순간부터 피검자가 이것을 감지하여 입력을 받기 위한 구간을 계산하여 피검자가 제대로 상승음을 감지하고 있는지 확인한다. 그림 3 은 각 쓰레드가 수행하 는 기능을 간단하게 나타내었다.

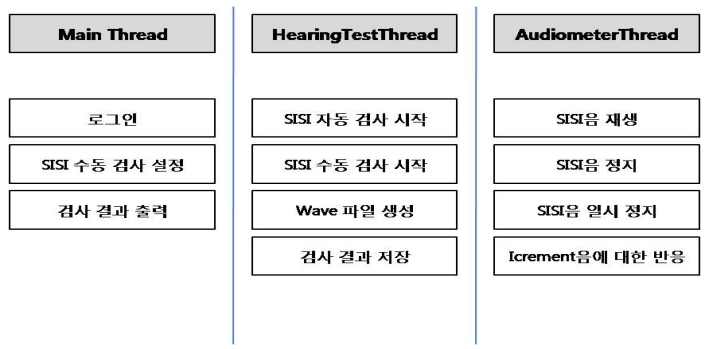

[그림 3] 각 쓰레드의 기능

\section{5 사용자 인터페이스}

본 논문의 SISI 검사 소프트웨어는 검사자 및 피검자 에게 검사 진행 시 편리한 인터페이스를 제공하기 위해 수동 모드와 자동 모드로 구성된다.

2 가지 모드의 인터페이스는 검사자가 검사 진행시 모 니터에서 확인하는 것으로 피검자는 방음실에서 SISI 검 사음의 상승 순간을 감지하여 키보드나 마우스 또는 전 용 입력장치를 통해 감지 순간을 이벤트로 보내주면 된 다.

\subsection{1 자동 모드}

자동 모드는 검사자의 개입 없이 이미 정의 되어있는 SISI 검사 시나리오에 따라 검사를 진행하는 모드이다.

그림 5 는 자동모드 검사의 사용자 인터페이스를 나타 낸다. 화면의 오른쪽, 왼쪽에 있는 오디오그램은 순음 청 력검사의 역치 값을 나타내기 위한 것이다. 그리고 SISI 검사 중 램프를 통해 검사음의 발생, 상승 순간, 피검자의 반응, 차폐음의 발생 등을 화면 중앙의 3 개의 램프를 통 해 확인할 수 있으며, 현재 진행되는 검사음의 정보 및 검사 결과를 오른쪽, 왼쪽 오디오그램 아래쪽에서 확인할 수 있다.

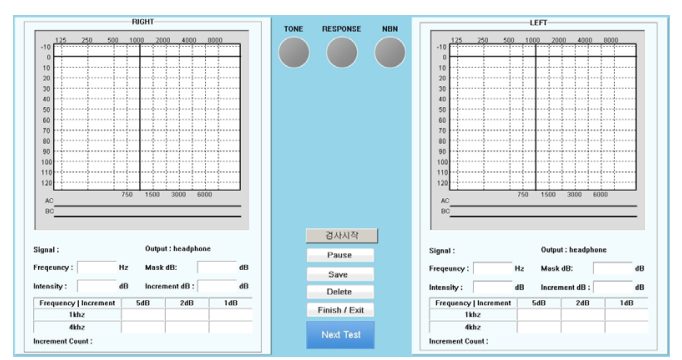

[그림 5] 자동 모드 검사 화면

자동모드에서는 $1 \mathrm{~dB}$ 상승 구간을 감지하기 위한 사전 훈련 과정을 진행한다. 우선 $5 \mathrm{~dB}$ 상승음을 10 번 들려주 고 만약 9 회 이상 반응을 하면 $2 \mathrm{~dB}$ 상승음을 10 번 들려 준다. $2 \mathrm{~dB}$ 역시 9 번 이상 반응을 하면 $1 \mathrm{~dB}$ 상승음을 20 회 들려준다. 만약 $5 \mathrm{~dB}$ 과 $2 \mathrm{~dB}$ 상승음을 10 번 중 9 번 이 상 반응을 하지 못할 경우에는 20 번 모두 진행한다. 피검 자의 각 주파수별 인지율에 대한 결과를 그림 5 에 나타낸 최 하단 화면에 출력한다.

\section{5 .2 수동 모드}

수동 모드는 정해진 검사 시나리오를 이용하지 않고 검사자가 피검자의 순음청력검사 결과를 확인하고 필요 한 상승 및 검사 횟수를 임의로 정하여 빠른 시간 안에 
필요한 결과 값을 획득 할 수 있는 모드이다. 따라서 자 동 모드에 비해 SISI 검사음을 설정(주파수, 상승 음압 $\mathrm{dB}, \mathrm{SISI}$ 기본 단위 음 발생 횟수)할 수 있는 부분이 추가 된다.

수동 모드의 장점은 피검자가 기본 단위의 SISI 검사 음에 대한 반응을 검사 도중 확인이 가능하다는 데 있다. 해당 검사의 인지율이 처음부터 높게 나타나는 경우 검 사를 도중 중단할 수 있어 다음 검사를 빠르게 진행 할 수 있다. 수동 모드 인터페이스는 그림 6과 같다.

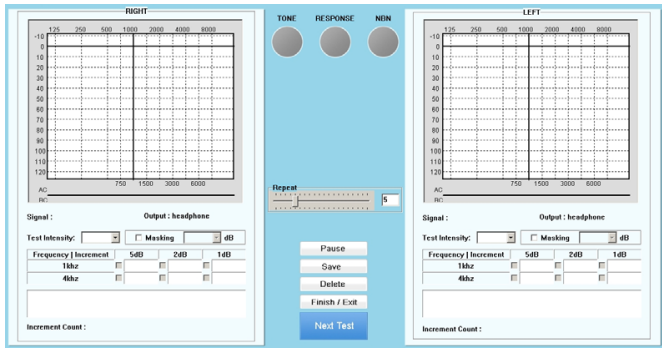

[그림 6] 수동 모드 검사 화면

\section{4. 시험 및 결과 평가}

\section{1 시험 환경 및 결과}

\section{1 .1 시험 환경}

개발된 SISI 청력검사 소프트웨어의 출력을 시험하였 으며, 시험 환경은 다음과 같다. SISI 검사음의 출력 전압 을 분석하기 위해서 사용된 오실로스코프는 Tektronix 사 의 DPO 3032 Digital Phosphor Oscilloscope 이며 시험에 사용된 컴퓨터는 $2.8 \mathrm{GHz}$ Intel Core 2 Duo E7200 프로 세서, 2G DDR2 메모리 그리고 VIA VT1708S 칩셋의 온 보드 사운드 카드로 구성된다. 운영체제는 마이크로소프 트 상의 Windows XP를 사용하였으며, 헤드폰은 Telephonics 사의 TDH-39를 사용하였다.

\subsection{2 시험 결과}

출력 전압의 파형은 SISI 검사음과 차폐음에 대해 출 력 전압을 각 주파수 별로 측정하여 확인하였다. 오실로 스코프에서 제공하는 캡처 기능을 이용하여 $1 \mathrm{KHz}$ 와 $4 \mathrm{KHz}$ 의 출력 파형을 획득하였다.

그림 7은 $1 \mathrm{KHz} 70 \mathrm{~dB} \mathrm{SPL}$ 의 출력 파형을 나타내었다. 그림에서 볼 수 있듯이 (a)와 (b)는 순음의 한 사이클에 대 한 시간을 나타낸다. 이 시간이 정확하게 $1 \mathrm{~ms}$ 가 됨은 이 순음이 $1 \mathrm{KHz}$ 의 주파수를 갖는다는 것을 보여준다.

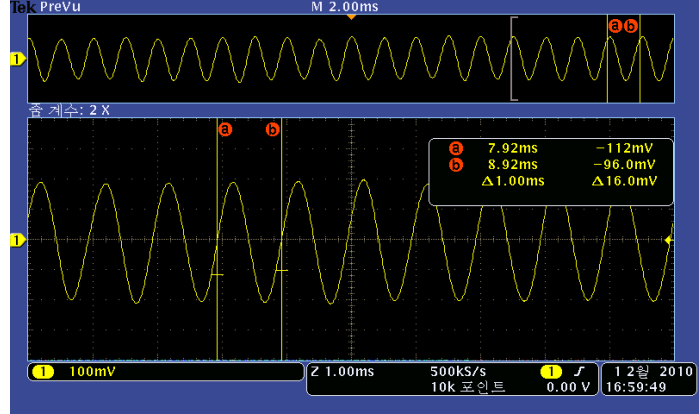

[그림 7] $1 \mathrm{KHz} 70 \mathrm{~dB}$ 출력 파형

SISI 검사음은 일정한 강도의 순음이 일정 시간동안 음압이 상승하는 상승음 부분을 가진다. 구현된 소프트웨 어에서는 상승음이 안정기에 도달하는 시간을 $50 \mathrm{~ms}$, 안 정기를 $200 \mathrm{~ms}$, 하강시간을 $50 \mathrm{~ms}$ 로 구분하였다.

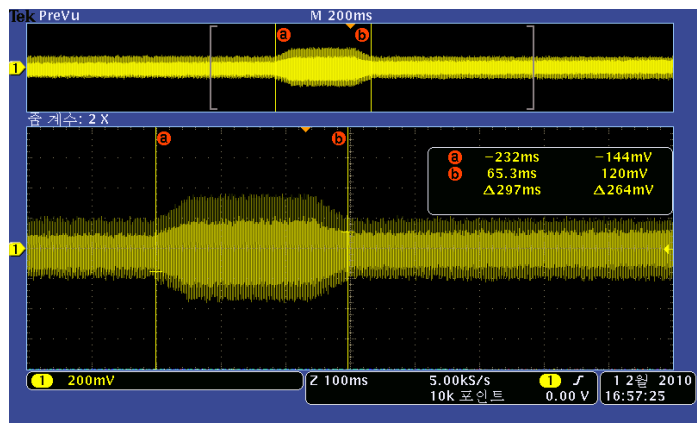

[그림 8] $1 \mathrm{KHz}, 70 \mathrm{~dB}$, 상승폭 $5 \mathrm{~dB}$ 출력 파형

그림 8 은 상승음의 폭이 $5 \mathrm{~dB}$ 인 $1 \mathrm{KHz} 70 \mathrm{~dB}$ 의 출력 파형을 보여준다. 그림 8 에서 (a)와 (b)는 상승음의 시작과 끝이 $300 \mathrm{~ms}$ 임을 나타내고 있다. 그림 9의 (a)와 (b)는 상 승음 안정기가 $200 \mathrm{~ms} \sim 250 \mathrm{~ms}$ 사이의 길이를 가지는 가 를 측정하였으며, 상승 및 하강 시간이 각각 $50 \mathrm{~ms}$ 이고, 안정기가 정확하게 $200 \mathrm{~ms}$ 임을 보여주고 있다.

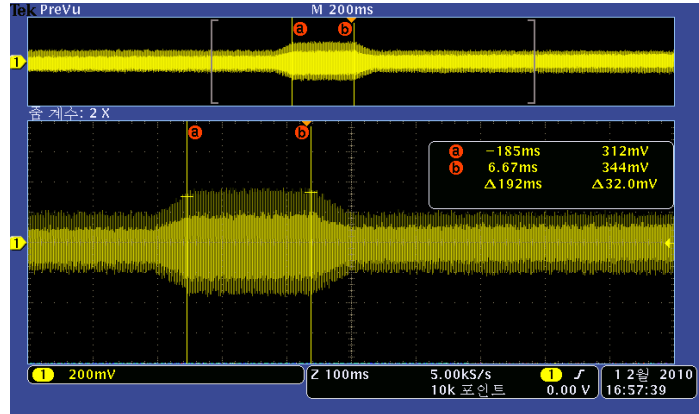

[그림 9] $1 \mathrm{KHz}, 70 \mathrm{~dB}$, 상승폭 $5 \mathrm{~dB}$ plateau 구간 
SISI 검사에서는 앞의 식 2.1을 만족할 경우 검사귀의 반대측 귀에 차폐음을 들려준다. 그림 10 은 $1 \mathrm{KHz}$ 의 주파 수를 가지고 식 2.2 에 의해 차폐량이 $50 \mathrm{~dB}$ 로 결정된 차 폐음의 출력 파형을 보여준다.

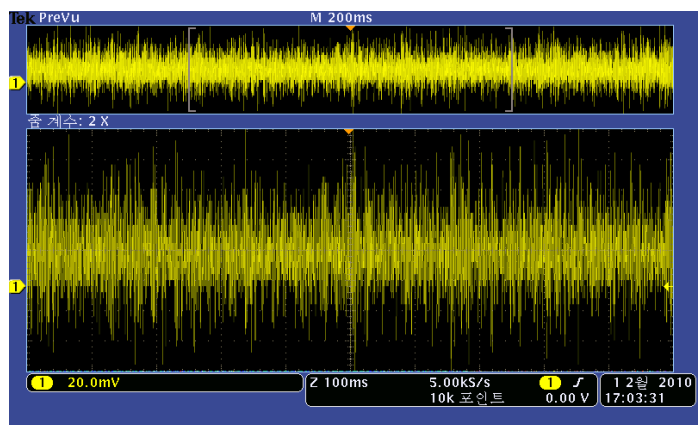

[그림 10] $1 \mathrm{KHz} 50 \mathrm{~dB}$ 차폐음 출력 파형

\section{2 결과 분석}

앞 절에 기술한 바와 같이 SISI 검사음에 대해 출력 파 형을 시험하였다. 그 결과 출력 순음은 정확한 주파수를 제공하고 있으며, 상승음의 상승 시간 및 하강 시간 그리 고 안정기 구간의 시간이 정확하게 출력됨을 확인할 수 있었다. 그리고 차폐가 필요한 경우 차폐음이 발생됨을 확인하였고, 그 경우 차페음의 출력 파형도 확인할 수 있 었다. 따라서 본 논문의 SISI 시스템은 기존의 이론적 기 반을 제공하는 논문에서 제시한 SISI 검사 시스템의 기능 을 충족함을 확인할 수 있었다.

\section{5. 결론 및 향후 계획}

본 논문은 누가현상 판별을 위해 사용되는 미세증가감 수지수 검사 프로그램을 기술하였다. 구현된 프로그램의 동작 과정 및 출력 음압은 시험을 통해 확인하였다. 본 논문의 SISI 검사 기능을 구현함으로써, 기존의 기도 및 골도에 추가하여 필요시 SISI 검사를 수행할 수 있게 함 으로써 정확한 병변의 원인을 파악할 수 있을 것으로 판 단한다.

본 시스템은 현재 피검자의 인지를 마우스를 통해 체 크하도록 구성되어 있다. 마우스 대신 간단하고 사용하기 쉬운 인터페이스를 제공하는 것은 향후 제품 개발 과정 에서 다룰 계획이다. 또 Self 모드 검사 기능을 추가함으 로써 보다 다양한 검사 기능을 제공할 계획이다.

\section{참고문헌}

[1] 김진동, 전계록, 왕수건, 신범주, “미세증감감수지수 검사와 자기청력검사를 이용한 난청 유형의 감별 진 단”, 한국전기전자재료학회논문지 제22권 제8호, 2009.8.

[2] 김진동, 신범주, 전계록, 왕수건, "다중모드 지원 자 동차폐 순음청력검사 시스템 개발”, 한국산학기술학 회논문지 제10권 제6호, 2009.6.

[3] 신승원외 4인, “음압 보정을 통한 이동형 청력 검사 시스템의 구현”, 전기학회논문지 제56권 6호, 2007.

[4] 고의경, 난청의 진단, 臨床耳鼻咽喉科 제 14 권 제 2 호, 2003.

[5] 한국산업안전공단, “순음청력 검사에 관한 지침”, 한 국산업안전공단, 2006.10.

[6] 전계록, 정동근, 김기련, 신범주, "심전도와 맥파 신호 검출을 위한 일체형 센서 시스템의 구현", 한국산학 기술학회 논문지 제 10 권 제 5 호, 2009.5

[7] British Society of Audiology, "Pure tone air and bone conduction threshold audiometry with and without masking and determination of uncomfortable loudness levels", BSA, Mar. 2004.

[8] S. H. Lee, Recruitment Phenomenon and Tone Decay Test. Clin Otol. Vol. 7, No. 2, 1996.

[9] K. S. Park, J. C. Lee , K. M. Chon, "Diagnostic Significance of SISI Test in Normal and Various Hearing Loss." Korean J of Otolaryng Vol 30, 1987.

[10] G. D. Hillman and J. E. Lane, "Real-Time Determination of IIR Coefficients for Cascaded Butterworth Filters", International Conference on Acoustics, Speech and Signal Processing, pp. 13531356, 1989.

[11] Darkoman, "CWave - Simple C++ Class to Maunipulate Wav Files", http://www.codeproject .com/KB/audio-video/CWave.aspx, 2008.

[12] Toby Opferman, "Playing .Wav files using the Windows Multi-Media Libray", http://www .codeproject.com/KB/audio-video/wavefiles.aspx, 2004.

[13] David B. Thomas and at. el, "Gaussian Random Number Generators", ACM Computing Surveys, Vol. 39, No. 4, 2007.

[14] Seymour Shlien and John Lodge, "Real-Time Generation of Narrow-Band Audio Noise", IEEE Signal Processing Letters Vol. 3 No. 41996.

[15] John Tomarakos, "The Relationship of Dynamic Range to Data Word Size in Digital Audio Processing", http://www.audiodesignline.com/show Article.jhtml?articleID=192200610, 2002. 


\section{강 덕 훈(Kang Deok Hun)}

[준회원]

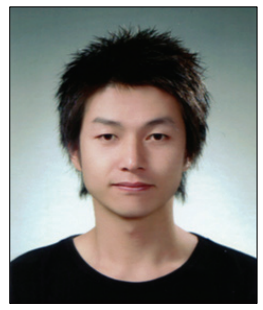

- 2009년 8월 현재 : 부산대학 교 대학원 바이오메디컬공학과 (공학석사과정)

<관심분야>

영상신호처리, 메디컬 소프트웨어 응용

송 복 득(Song Bok Deuk)

[정회원]

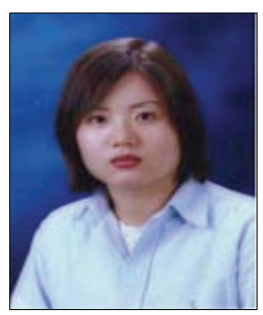

- 2004년 2월 : 동서대학교 소프트 웨어전문대학원 소프트웨어학과 (공학석사)

- 2009년 8월 현재 : 부산대학 교 대학원 바이오메디컬공학과 (공학박사과정)

<관심분야>

영상신호처리, 머신 비젼, 메디컬 소프트웨어 응용

\section{신 범 주(Bum Joo Shin)}

[정회원]

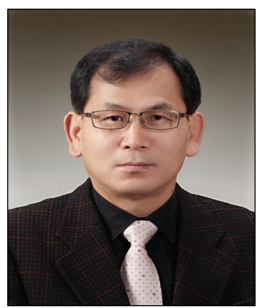

- 1991년 2월 : 경북대학교 대학원 컴퓨터공학과(공학석사)

- 1998년 8월 : 경북대학교 대학원 컴퓨터공학과(공학박사)

- 1987년 3월 2002년 2월 : 한 국전자통신연구원 책임연구원

- 2006년 3월 현재 : 부산대학 교 바이오메디컬공학과 부교수

<관심분야>

센서시스템, 메디컬 소프트웨어 응용
이 광 호(Lee Kwang Ho)

[정회원]

- 1985년 2월 : 경북대학교 대학원 전자공학과(공학석사)

- 1992년 2월 : 경북대학교 대학원 전자공학과 (공학박사)

- 1988년 10월 현재 : 경일대학 교 전자정보통신공학과 교수

\section{<관심분야>}

영상신호처리, 3차원 물체 인식, 신경회로망

\section{김 진 동(Kim Jin Dong)}

[정회원]

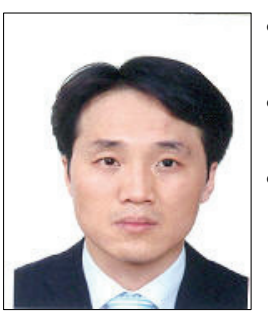

- 2006년 2월 : 부산대학교 대학원 의학과(의학석사)

- 2008년 3월 현재 : 부산대학 교 대학원 의공학협동과정

- 1999년 5월 현재 : 부산대학 교병원 이비인후과

\section{<관심분야>}

신호처리, 생체계측, 의공학

전 계 록(Gye Rok Jeon)

[정회원]

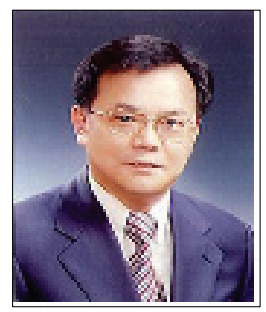

- 1982년 2월 : 부산대학교 대학원 전자공학과 (공학석사)

- 1993년 2월 : 동아대학교 대학원 전자공학과 (공학박사)

- 1985년 3월 현재 : 부산대학 교 의과대학 교수

<관심분야>

의용계측, 영상신호처리, 생체시스템 모델링 
왕 수 건(Soo Geun Wang)

[정회원]

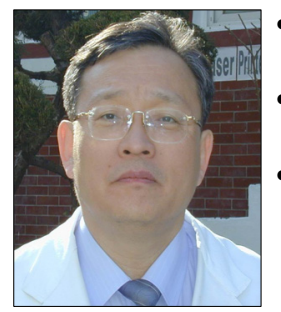

- 1981년 2월 : 부산대학교 대학원 의학과(의학석사)

- 1988년 2월 : 부산대학교 대학원 의학과(의학박사)

- 1987년 10월 현재 : 부산대학 교 의학전문대학원 교수

<관심분야> 